\title{
Gambaran Proses Penerimaan Diri pada Pria Usia Dewasa Awal dengan HIV/AIDS
}

\author{
ANAZSTASYA PUTRI \& TRI KURNIATI AMBARINI* \\ Fakultas Psikologi Universitas Airlangga
}

\begin{abstract}
ABSTRAK
Penelitian ini bertujuan untuk mengetahui gambaran proses penerimaan diri pada pria berusia dewasa awal dengan HIV/AIDS. Penerimaan diri pada ODHA sendiri mengacu pada stigma dan diskriminasi yang didapatkan oleh ODHA dari masyarakat sekitar. Penelitian ini menggunakan metode penelitian kualitatif dengan pendekatan fenomenologi. Penggalian data dilakukan dengan wawancara. Teknik analisis data yang digunakan adalah metode Analisis Fenomenologis Interpretatif (AFI). Pencarian partisipan pada penelitian ini menggunakan link Google Form yang disebarkan melalui beberapa sosial media khususnya Twitter. Jumlah partisipan pada penelitian ini berjumlah dua orang dimana seluruh partisipan merupakan orang dengan HIV/AIDS yang berjenis kelamin pria dan pada usia perkembangan dewasa awal. Berdasarkan hasil wawancara dan analisis yang telah dilakukan, dapat ditarik kesimpulan bahwa masing masing partisipan sudah melewati tahap penerimaan diri hingga pada fase acceptance. Namun, terdapat perbedaan fase yang dilewati oleh masing-masing partisipan. proses penerimaan diri partisipan juga dipengaruhi oleh beberapa aspek akan berperan positif dalam proses penerimaan diri.
\end{abstract}

Kata kunci: dewasa awal, HIV, penerimaan diri.

\begin{abstract}
This study aims to describe the self-acceptance process in early adult men with HIV/AIDS. Selfacceptance of PLWHA itself refers to the stigma and discrimination that PLWHA gets from the surrounding community. This study uses a qualitative research method with a phenomenological approach. Data mining was carried out by interview. The data analysis technique used is the Interpretative Phenomenological Analysis (AFI). The search for the subjects for this research using link from Google Form and distributed through social media especially Twitter. The number of subjects in this study was two people where all subjects were people with HIV/AIDS who were male and at the age of early adulthood. Based on the results of interviews and the analysis, it can be concluded that each subject has passed the self-acceptance stage to the acceptance phase. However, there are different phases that each subject goes through, the self-acceptance process of participants is also influenced by several aspects that will play a role in the self-acceptance process.
\end{abstract}

Keywords: early adulthood, HIV, self-acceptance

Buletin Penelitian Psikologi dan Kesehatan Mental (BRPKM), 2021, Vol. 1(1), 715-722

*Alamat korespondensi: Fakultas Psikologi Universitas Airlangga, Kampus B Universitas Airlangga Jalan Airlangga 4-6 Surabaya 60286. Surel: tri.ambarini@psikologi.unair.ac.id

Naskah ini merupakan naskah dengan akses terbuka dibawah ketentuan the Creative Common Attribution License (CC-BY-4.0) (http://creativecommons.org/licenses/by/4.0), 
sehingga penggunaan, distribusi, reproduksi dalam media apapun atas artikel ini tidak dibatasi, selama sumber aslinya disitir dengan baik.

\section{PE N D A H U L U A N}

HIV (Human Immunodeficiency Virus) sendiri adalah retrovirus yang menjangkit pada manusia yang menyerang sistem kekebalan tubuh manusia serta mengganggu atau merusak fungsinya. Adanya stigma yang berkembang di masyarakat dikarenakan HIV dan AIDS merupakan penyakit menular dan membuat cemas serta anggapan bahwa ODHA adalah orang yang melanggar norma dan agama berdampak pada adanya diskriminasi akan ODHA oleh masyarakat sekitar bahkan oleh keluarganya. Stigma berasal dari pemikiran dan keyakinan masyarakat bahwa seseorang yang terjangkit HIV/AIDS merupakan akibat dari perilaku amoral yang tidak dapat diterima oleh kebanyakan orang (Sarikusuma \& Hasanah, 2012). Stigma dari masyarakat dapat dilihat dari perlakuan negatif berupa penghindaran, penghinaan, penolakan dalam pergaulan sosial, dan kehilangan pekerjaan (Li, dkk., 2012). Keputusasaan dan stigma negatif berdampak pada rendahnya keinginan dalam mencari pelayanan kesehatan serta adanya kecenderungan untuk mengabaikan strategi dalam mengatasi stress yang akhirnya mengarah kepada mengisolasi diri dari lingkungan sekitar dan tingginya resiko bunuh diri (Valencia-Garcia dkk., 2008). Dikarenakan Infeksi virus HIV/AIDS yang sifatnya menular dan belum ditemukan obatnya, sehingga dianggap sebagai penyakit yang mengerikan. Pandangan ini memengaruhi penerimaan masyarakat terhadap orang yang positif terinfeksi virus HIV. Akibatnya ODHA sering dikucilkan dan dijauhi dalam pergaulan di masyarakat, lingkungan sekitar yang tidak mendukung dapat memengaruhi tingkat penerimaan diri pada ODHA (Ardani \& Handayani, 2017).

Tingkat penolakan masyarakat dan lingkungan yang tinggi akan kehadiran orang yang terinfeksi HIV/AIDS menyebabkan sebagian ODHA harus hidup dengan menyembunyikan status (Shaluhiyah, dkk., 2015). Selain itu, berdasarkan hasil penelitian Putra, dkk. (2019) keseluruhan partisipan penelitian merasakan kesedihan dan kegagalan dalam hidupnya akibat HIV/AIDS yang diderita, partisipan juga merasa masalah yang datang tidak juga berhenti serta merasa tidak puas dengan hidupnya, hal tersebut juga dapat memengaruhi tingkat penerimaan diri seseorang yang terjangkit HIV/AIDS. Depresi pada orang yang terinfeksi HIV berkaitan langsung dengan perubahan neurobiologis yang disebabkan oleh penyebaran HIV di sistem saraf pusat. ODHA memiliki risiko dua kali lipat mengalami gangguan kesehatan jiwa seperti depresi dan kecemasan dibandingkan dengan orang sehat pada umumnya. Hal ini berpengaruh pada menurunnya fungsi kekebalan tubuh, kualitas hidup, tingkat kepatuhan terhadap pengobatan, sehingga secara signifikan berkontribusi terhadap terjadinya kematian dini (Agus dkk., 2019). Seseorang dengan HIV/AIDS pada dewasa awal akan merasa tidak diterima di lingkungannya karena stigma di masyarakat yang negatif akan orang dengan HIV/AIDS, orang dengan HIV/AIDS juga merasa tidak puas dengan kehidupannya karena adanya batasan dari lingkungan terhadap mereka. Adanya rasa bersalah kepada diri sendiri dan keluarga karena seseorang pada masa dewasa awal merupakan masa di mana adanya tuntutan untuk membangun prestasi dan karir yang menjadi harapan keluarga terutama pada pria, namun dapat terhambat karena penyakit yang diderita oleh orang dengan HIV/AIDS. Tekanan dan tuntutan yang dirasakan pada masa dewasa awal pada orang dengan HIV/AIDS dapat menimbulkan depresi dan kecemasan, keadaan psikologis tersebut memengaruhi tingkat kecenderungan seseorang dengan HIV/AIDS untuk dapat menerima keadaan dirinya.

\section{E T O D E}




\section{Desain Penelitian}

Pada penelitian ini penulis menggunakan metode penelitian kualitatif. Pendekatan ini dipilih karena dapat memberikan gambaran suatu fenomena secara menyeluruh serta menghasilkan data deskripti (Poerwandari, 2007). Tipe penelitian yang digunakan adalah studi fenomenologi. Studi fenomenologi adalah sebuah metodologi kualitatif yang mengizinkan peneliti menerapkan dan mengaplikasikan kemampuan subjektivitas dan interpersonalnya dalam proses penelitian eksploratori (Helaluddin, 2018).

\section{Partisipan}

Pada penelitian ini penulis menggunakan metode penelitian kualitatif. Penelitian kualitatif didefinisikan sebagai metodologi yang menyediakan alat-alat dalam memahami arti secara mendalam yang berkaitan dengan fenomena yang kompleks dan prosesnya dalam praktik kehidupan sosial (Brady, 2015).

Tipe penelitian yang digunakan adalah studi fenomenologi. Studi fenomenologi adalah sebuah metodologi kualitatif yang mengizinkan peneliti menerapkan dan mengaplikasikan kemampuan subjektivitas dan interpersonalnya dalam proses penelitian eksploratori (Helaluddin, 2018). Partisipan pada penelitian ini adalah partisipan utama. Partisipan utama merupakan seseorang yang mengidap HIV/AIDS, berusia dewasa awal dan bejenis kelamin pria. Metode member check digunakan untuk melakukan teknik pemantaban kredibilitas dan menggali data secara lebih dalam. Partisipan utama penelitian dipilih berdasarkan kriteria: a. berjenis kelamin pria; b. berusia 18-40 tahun; c. mengidap HIV/AIDS.

Krtiteria-kriteria tersebut disebar dengan poster elektronik yang menyertakan link google form di sosial media. Google form yang disebar sudah menyertakan informed consent untuk mengikuti penelitian. Dengan mengisi google form tersebut, partisipan yang memenuhi kriteria dan bersedia untuk mengikuti penelitian akan dihubungi secara personal untuk proses penelitian lebih lanjut yaitu observasi dan wawancara. Peneliti mendapatkan 38 responden yang sesuai dengan kriteria, namun hanya 31 di antaranya yang bersedia untuk melanjutkan pada sesi wawancara. Untuk mempersempit lagi, peneliti menyeleksi lagi beberapa partisipan dan dari sini hanya tersisa 6 partisipan yang selanjutnya dihubungi kembali dan mendapatkan 2 partisipan yang menkonfirmasi ketersediaanya sebagai partisipan wawancara dan bersedia melakukan wawancara via video call maupun wawancara tatap muka. Selanjutnya, peneliti memberikan informed consent dan meminta tanda tangan partisipan apabila menyetujui keterlibatannya dengan penelitian yang dilakukan. Terakhir, peneliti menetapkan jadwal dengan partisipan dan melakukan wawancara di waktu yang telah disepakati.

\section{Strategi Pengumpulan Data}

Menurut Lincoln \& Guba (1985) wawancara dapat dilakukan untuk mengonstruksi perihal orang, kejadian, kegiatan, organisasi, perasaan, motivasi, tuntutan, kepedulian, merekonstruksi kebulatan harapan pada masa yang akan datang, memverifikasi, mengubah, dan memperluas informasi dari berbagai sumber, dan mengubah atau memperluas konstruksi yang dikembangkan peneliti sebagai triangulasi. Teknik wawancara dipilih peneliti untuk memperoleh data yang lebih banyak, akurat dan mendalam. Model wawancara yang digunakan adalah wawancara mendalam.

Bersamaan dengan adanya pandemi global COVID-19, pemerintah membatasi adanya aktivitas sosial. Oleh sebab itu, kemungkinan besar proses pengambilan data akan dilaksanakan secara daring. 
Prinsip-prinsip etis dari informed consent, anonimitas dan kerahasiaan dipatuhi sepanjang proses pengumpulan dan analisis data. Partisipasi sepenuhnya bersifat sukarela dan responden diberikan informasi adanya hak yang akan mereka dapatkan dan bahwa mereka diperbolehkan untuk mundur pada setiap tahap proses penelitian. Karena penelitian berbasis wawancara memiliki sifat pribadi, peserta diberi tahu tentang hak mereka untuk memilih untuk tidak menjawab pertanyaan yang mereka tidak ingin jawab. Semua peserta dirujuk dengan nama samaran atau inisial yang sudah disepakati.

\section{Analisis Data}

Teknik analisis data yang dipilih dalam penelitian ini menggunakan analisis data kualitatif yang dilakukan dalam penelitian fenomenologi ini yaitu menggunakan metode Interpretative Phenomenological Analysis (IPA). Menurut Smith (Hajaroh, 2010) memaparkan tahap-tahap Interpretative Phenomenological Analysis, yaitu 1) Reading and re-reading, 2) Initial noting, 3) Developing Emergent Themes, 4) Searching for connection a cross emergent themes, 5) Moving the next cases dan 6) Looking for patterns across cases.

Untuk melakukan kredibilitas penelitian ini dengan menggunakan metode member check. Metode member check merupakan cara untuk mendapatkan kredibilitas penelitian melalui pemeriksaan data oleh pemberi data atau partisipan.

\section{HAS I L P E N EL I T I A N}

Pengalaman HIV/AIDS

Partisipan AN

Partisipan terdiagnosa positif HIV/AIDS sejak bulan Juli tahun 2018, partisipan tertular virus HIV/AIDS dikarenakan oleh hubungan oral bersama mantan pasangan partisipan yang ternyata mengidap HIV/AIDS dan sudah dua tahun tidak melanjutkan treatment ARV. partisipan mulai merasa aneh dengan berat badannya yang stuck sedangkan pada saat itu partisipan cukup sering makan bersama temantemannya hingga akhirnya pada Juni 2018 partisipan memutuskan untuk memeriksakan kondisi partisipan dengan mengikuti screening VCT di salah satu yayasan yang berada di Yogyakarta. Reaksi partisipan saat mengetahui hasil cek darah saat screening VCT dan menunjukkan bahwa partisipan positif HIV adalah partisipan sempat mengira masa depannya akan hancur. Saat partisipan mengetahui akan statusnya sebagai ODHA, partisipan memberitahukan hal ini kepada teman-teman dekat partisipan dan juga keluarga partisipan.

Partisipan UK

Partisipan terdiagnosa positif HIV/AIDS sejak bulan September 2019 yang disebabkan oleh hubungan seksual bersama mantan pasangan partisipan yang dari awal tidak mengakui bahwa mantan pasangan partisipan sudah terdiagnosa positif HIV/AIDS. Partisipan juga mengalami gejala seperti demam, nafsu makan berkurang, diare, gatal dan ruam pada kulit, namun setelah dicek ke dokter dan melakukan beberapa pemeriksaan tidak ada hasil yang pasti dari gejala yang dialami partisipan. Akhirnya pada bulan September 2019 partisipan melakukan tes HIV di PUSKESMAS dekat rumahnya dan hasil tes tersebut menyatakan bahwa partisipan positif HIV. Saat partisipan mengetahui bahwa ia positif HIV, partisipan menangis dan takut akan masa depannya juga merasa takut orang tua dan lingkungan partisipan tidak akan menerima keadaan partisipan. 


\section{Dewasa Awal}

\section{Partisipan AN}

Partisipan sebagai individu yang sudah memasuki usia dewasa awal, aktif mengikuti berbagai kegiatan baik organisasi maupun kelompok sosial. Selain memiliki teman yang banyak dan kelompok pertemanan, partisipan juga bergabung dengan kelompok sosial ODHA se-Indonesia. Partisipan juga sempat bekerja sebagai customer service, fasilitator forum anak, pendamping perempuan korban kekerasan dan MC. Partisipan berencana untuk mengikuti tes CPNS karena partisipan ingin bekerja di instansi pemerintahan dan partisipan juga memiliki keinginan menjadi dosen.

\section{Partisipan UK}

Partisipan saat ini bekerja di sebuah perusahaan retail di Jakarta, walaupun partisipan sempat memiliki keinginan untuk resign karena ingin berfokus pada kesehatannya namun partisipan mengurungkan niat dan melanjutkan karirnya hingga saat ini. Partisipan sempat memiliki hubungan dengan seorang wanita namun hubungan tersebut sudah tidak berlanjut. Partisipan berencana untuk menikah walaupun partisipan mempertanyakan apakah ada yang bersedia menerima keadaan partisipan sebagai ODHA, namun partisipan juga tidak terburu-buru untuk segera mencari pasangan dan menikah. Selain memiliki beberapa teman dekat di kantor, partisipan juga sesekali berinteraksi dengan tetangga partisipan dan partisipan juga tergabung dalam kelompok ODHA.

\section{Penerimaan Diri}

\section{Partisipan AN}

Pada fase denial, partisipan merasa ada kejanggalan yang terjadi pada tubuhnya di mana partisipan merasa berat badannya stuck dan juga merasa ada sesuatu pada dirinya hingga akhirnya partisipan memutuskan untuk memeriksakan keadaannya. Partisipan sempat mengalami fase anger di mana partisipan merasa kecewa dan marah setelah terdiagnosa positif HIV/AIDS. Partisipan juga sempat merasa bahwa masa depannya akan hancur karena kondisi kesehatannya saat ini, namun fase tersebut hanya terjadi beberapa hari saja pada partisipan. Pada fase bargaining, partisipan sempat merasa masa depannya akan hancur namun partisipan berpikir bahwa partisipan sudah mengetahui akan risiko dari tindakan seksualnya, partisipan juga sudah teredukasi mengenai HIV dan teman-teman partisipan yang terinfeksi HIV banyak yang keadaannya baik-baik saja.

Pada fase acceptance partisipan pada awal terdiagnosa lebih mempertanyakan apa yang harus ia lakukan selanjutnya dengan kondisinya saat ini, partisipan juga merasa senang dan ada kepuasan tersendiri ketika ia dapat membantu orang lain dengan statusnya sebagai ODHA. Partisipan juga merasa statusnya sebagai ODHA bukan akhir dari segalanya melainkan sebagai bentuk kasih oleh Tuhan kepada dirinya. Partisipan juga sudah merasa puas dengan apa yang dimiliki saat ini namun partisipan juga selalu ingin belajar dan ingin mengejar cita-citanya.

\section{Partisipan UK}

Pada fase denial, partisipan mengalami berbagai gejala medis seperti diare, ruam pada kulit, berat badan turun dan gatal. Partisipan sudah melakukan berbagai tes Kesehatan namun tidak ada hasil yang menunjukkan bahwa partisipan memiliki penyakit tertentu. Partisipan mencari tahu mengenai penyakitnya dan partisipan sudah melakukan tes-tes terkait penyakitnya namun tinggal tes HIV yang belum partisipan lakukan. Partisipan pada saat itu belum melakukan tes HIV karena takut akan hasilnya namun pada akhirnya partisipan melakukan tes HIV dan hasilnya menyatakan bahwa partisipan positif HIV/AIDS. Setelah terdiagnosa, partisipan kehilangan nafsu makan karena stress akan penyakitnya dan 
masih denial dengan keadaannya pada saat itu. Pada fase bargaining, partisipan merasa banyak temannya yang membutuhkan pertolongannya dan merasa harus membantu orang lain hingga akhirnya partisipan membuat akun Twitter sebagai sarana edukasi mengenai HIV/AIDS. Partisipan mengalami fase depression di mana saat terdiagnosa positif HIV/AIDS partisipan menangis karena merasa tidak memiliki masa depan dan takut tidak diterima oleh lingkungan sekitar. Partisipan juga pernah melakukan percobaan mengakhiri hidup dan adanya keinginan untuk mengakhiri hidup selama kurang lebih satu tahun. Pada fase acceptance partisipan merasa bahwa ia harus happy dengan keadaannya, partisipan juga merasa berguna dengan statusnya saat ini karena ia dapat membantu orang lain dengan mengedukasi mengenai HIV/AIDS melalui akun Twitternya. Partisipan juga bersyukur dengan keadaannya saat ini meskipun masih ada beberapa keinginan yang ingin dicapai, partisipan juga merasa terlahir kembali sejak statusnya sebagai ODHA dan merasa statusnya saat ini bukan penghalang bagi partisipan untuk lebih maju ke depannya.

\section{I S K U S I}

Gambaran proses penerimaan diri yang berbeda pada setiap partisipan dapat dijelaskan melalui tahapan penerimaan diri milik Kubler-Ross, tahapan pada masing-masing partispan pun memiliki keunikan tersendiri. Tidak semua partisipan melalui tahapan yang sama.

Pada fase denial di mana pada fase ini individu membentuk sebuah defense mechanism yang membantu ia untuk bertahan dari perasaan kehilangan. Ini dapat diekspresikan dengan berupa penolakan terhadap realitas. Hal ini terjadi pada kedua partisipan dimana pada partisipan 1 merasa ada kejanggalan yang terjadi pada tubuhnya di mana partisipan merasa berat badannya stuck dan juga merasa ada sesuatu pada dirinya hingga akhirnya partisipan memutuskan untuk memeriksakan keadaannya dan pada partisipan 2 mengalami berbagai gejala medis seperti diare, ruam pada kulit, berat badan turun dan gatal. Partisipan sudah melakukan berbagai tes Kesehatan namun tidak ada hasil yang menunjukkan bahwa partisipan memiliki penyakit tertentu. Partisipan mencari tahu mengenai penyakitnya dan sudah melakukan tes-tes terkait penyakitnya namun tinggal tes HIV yang belum partisipan lakukan. Partisipan pada saat itu belum melakukan tes HIV karena takut akan hasilnya namun pada akhirnya partisipan melakukan tes HIV dan hasilnya menyatakan bahwa partisipan positif HIV/AIDS. Setelah terdiagnosa partisipan kehilangan nafsu makan karena stress akan penyakitnya dan masih denial dengan keadaannya pada saat itu.

Pada fase anger dirasakan oleh partisipan pertama, di mana pada fase ini individu menyadari bahwa proses menyangkal tidak dapat diteruskan. Sehingga mengekspresikannya dengan perasaan ingin melawan atau melakukan tindakan pemberontakan, seperti amarah dan iri hati (Lim, 2013). Partisipan 1 sempat mengalami fase anger di mana partisipan merasa kecewa dan marah setelah terdiagnosa positif HIV/AIDS namun fase ini hanya terjadi beberapa hari saja

Pada fase bargaining, keseluruhan partisipan pada penelitian ini pernah melakukan penawaran terhadap rasa sakit yang mereka terima. Pada subjek pertama karena partisipan pertama merupakan pendaping edukatif pada sebuah yayasan ODHA sehingga partisipan sudah teredukasi mengenai HIV/AIDS. Partisipan pun menyadari tindakan berisiko yang dilakukannya meningkatkan risiko tertular HIV/AIDS. Sedangkan pada partisipan kedua merasa banyak temannya yang membutuhkan pertolongannya dan meraasa harus membantu orang lain hingga akhirnya partisipan membuat akun Twitter sebagai sarana edukasi mengenai HIV/AIDS.

Pada fase depression hanya terjadi pada partisipan kedua saja di mana partisipan merasa sedih karena merasa sejak dinyatakan sebagai ODHA partisipan tidak akan memiliki masa depan. Partisipan juga 
sempat ingin melakukan percobaan mengakhiri hidup dengan ingin menabrakan diri ke tiang di jalan raya dan partisipan memiliki pemikiran untuk mengakhiri hidup selama kurang lebih satu tahun.

Pada tahapan acceptance/menerima diri, ini individu menerima kehilangannya dan tidak hanya berusaha menanggungnya. Mulai memahami bahwa kehilangan itu bukan kesalahan yang mereka perbuat dan mencari jalan keluar atas masalah dan rasa sakit yang dihadapinya (Lim, 2013). Pada fase ini kedua partisipan sudah dapat menerima diri mereka masing-masing. Pada partisipan 1 terbukti dengan merasa berguna karena dapat membantu orang lain, partisipan juga menyadari kelebihan dan kekurangan yang dimiliki serta partisipan percaya bahwa statusnya sebagai ODHA bukan akhir dari segalanya. Juga dengan partisipan 2 yang menyadari kelebihannya dan tidak merasa kekurangannya sebagai penghalang. Partisipan juga merasa teman-teman partisipan membutuhkannya dan partisipan juga ingin membantu orang lain. Partisipan pun mengutamakan kebahagiaan dan kesehatannya.

\section{S I M P U L A N}

Berdasarkan hasil penelitian mengenai proses penerimaan diri pada pria usia dewasa awal dengan HIV/AIDS dapat ditarik kesimpulan bahwa masing-masing subjek telah melewati berbagai fase penerimaan diri seperti denial, anger, bargaining hingga akhirnya mencapai tahap acceptance, walaupun pada fase depression hanya dilalui oleh salah satu partisipan saja. Dengan perbedaan fase dan waktu namun masing-masing partisipan dapat mencapai tahap acceptance atau menerima diri mereka sebagai ODHA. Selain itu, faktor-faktor seperti harapan yang realistis, kondisi lingkungan yang mendukung untuk mencapai harapan, kemampuan sosial yang baik, dan penyesuain diri yang baik akan berperan positif dalam proses penerimaan diri. Sementara konsep diri yang stabil pada penelitian ini tidak berperan dalam proses penerimaan diri seseorang.

\section{U C A P A N T ER I MAKASIH}

Terima kasih kepada Ibu Tri Kurniati Ambarini, Ibu Endang R. Surjaningrum, dan Ibu Ika Yuniar Cahyanti yang telah membimbing saya hingga tahap ini. Juga kepada kedua orang tua dan keluarga saya yang senantiasa memberikan dukungan dan menyayangi saya hingga menjadi pribadi seperti ini.

\section{DEKLARASI POTENSI TERJADINYA KONFLIK KEPENTINGAN}

Anazstasya Putri dan Tri Kurniati Ambarini tidak bekerja, menjadi konsultan, memiliki saham, atau menerima dana dari perusahaan atau organisasi manapun yang mungkin akan mengambil untung dari diterbitkannya naskah ini.

\section{PUSTAKA ACUAN}

Agus, D. F., Effendy, E., \& Camellia, V. (2019). Screening of Anxiety and Depression Related CD4 Count of People Living with HIV/AIDS with Anti-Retroviral in Medan, Indonesia. Macedonian Journal of Medical Science, 7(16).

Ardani, I., \& Handayani, S. (2017). Stigma terhadap orang dengan HIV/AIDS (ODHA) sebagai hambatan pencarian pengobatan: Studi Kasus pada Pecandu Narkoba Suntik di Jakarta. Indonesian Bulletin of

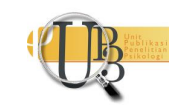


Health Research, 45(2), 81-88.

Brady, S. R. (2015). Utilizing and Adapting the Delphi Method for Use in Qualitative Research. International Journal of Qualitative Methods, 14(5), 1609406915621381.

Hajaroh, M. (2010). Paradigma, Pendekatan Dan Metode Penelitian Fenomenologi. UNY Press.

Helaluddin, H. (2018). Mengenal lebih Dekat dengan Pendekatan Fenomenologi: Sebuah Penelitian Kualitatif. Article: UIN Sultan Maulana Hasanuddin Banten.

Li, X., Wang, H., He, G., Fennie, K., \& Williams, A. B. (2012). Shadow On My Heart: A Culturally Grounded Concept Of HIV Stigma Among Chinese Injection Drug Users. Journal of the Association of Nurses in AIDS Care, 23(1), 52-62.

Lim, W. . (2013). Revisiting KUBLER-ROSS' S Five Stages Of Grief. . Journal of Social Sciences. Journal of Social Sciences, 9(1), 11.

Lincoln, Y. S., \& Guba, E. G. (1985). Naturalistic Inquiry. Sage.

Poerwandari, E. K. (2007). Pendekatan Kualitatif: Penelitian Perilaku Manusia. Lembaga Sarana Pengukuran Dan Pendidikan Psikologi (LPSP3), Fakultas Psikologi UI.

Putra, I., Hakim, M. Z., \& Heryana, W. (2019). Keinginan Bunuh Diril Orang Dengan HIV Dan AIDS (ODHA) Dampingan Yayasan PKBI DKI. Jurnal Ilmiah Rehabilitasi Sosial, 1(1).

Sarikusuma, H., \& Hasanah, N. (2012). Konsep diri orang dengan HIV dan AIDS (ODHA) yang menerima label negatif dan diskriminasi dari lingkungan sosial. Psikologia: Jurnal Pemikiran Dan Penelitian Psikologi, 7(1), 29-40.

Shaluhiyah, Z., Musthofa, S. B., \& Widjanarko, B. (2015). Stigma Masyarakat terhadap Orang Dengan HIV/AIDS. Kesmas: National Public Health Journal, 9(4), 333.

Valencia-Garcia, D., Starks, H., Strick, L., \& Simoni, J. M. (2008). After the fall from grace: negotiation of new identities among HIV-positive women in Peru. Culture, Health \& Sexuality, 10(7), 739-752. 